\title{
Ethnomedicinal plants used for snakebite treatments in Ethiopia: a comprehensive overview
}

\author{
Abraham Yirgu',* (1), Jean-Philippe Chippaux ${ }^{2,3}$ (1) \\ ${ }^{1}$ Central Ethiopia Environment and Forest Research Center, Addis Ababa, Ethiopia. \\ ${ }^{2}$ MERIT, IRD, Paris Descartes University, Sorbonne Paris Cité, Paris, France. \\ ${ }^{3}$ Centre de Recherche Translationnelle, Institut Pasteur, Paris, France.
}

\author{
Keywords: \\ Ethnobotany \\ Medicinal plant \\ Traditional treatment \\ Snakebite \\ Envenomation \\ Sub-Saharan Africa \\ Ethiopia
}

\begin{abstract}
Traditional medicine plays an important role in the daily lives of people living in rural parts of Ethiopia. Despite the fact that Ethiopia has a long history of using traditional medicinal plants as an alternative medicine source, there is no checklist compiling these plants used for snakebite treatment. This review collected and compiled available knowledge on and practical usage of such plants in the country. A literature review on medicinal plants used to treat snakebites was conducted from 67 journal articles, PhD dissertation and MSc theses available online. Data that summarize scientific and folk names, administration methods, plant portion used for treatment and method of preparation of recipes were organized and analyzed based on citation frequency. The summarized results revealed the presence of 184 plant species distributed among 67 families that were cited for treating snakebite in Ethiopia. In this literature search, no single study was entirely dedicated to the study of traditional medicinal plants used for the treatment of snakebite in Ethiopia. Most of the species listed as a snakebite remedy were shrubs and climbers (44\%) followed by herbs (33\%) and trees (23\%). Fabaceae was the most predominant family with the greatest number of species, followed by Solanaceae and Vitaceae. Remedies are mainly prepared from roots and leaves, through decoctions, infusions, powders and juices. Most remedies were administered orally (69\%). The six most frequently mentioned therapeutically important plants were Nicotiana tabacum, Solanum incanum, Carissa spinanrum, Calpurnia aurea, Croton macrostachyus and Cynodon dactylon. Authors reviewed the vegetal substances involved in snakebite management and their action mode. In addition to screening the biologically active ingredients and pharmacological activities of these plant materials, future studies are needed to emphasize the conservation and cultivation of important medicinal plants of the country.
\end{abstract}

* Correspondence: abrahamyirguw@gmail.com http://dx.doi.org/10.1590/1678-9199-JVATITD-2019-0017 Received: 03 April 2019; Accepted: 07 June 2019; Published online: 05 August 2019 


\section{Background}

Snakebite is a major public health issue, particularly in subSaharan Africa (SSA) [1, 2]. More than 95\% of envenomations occur in rural areas, involving persons in agricultural and pastoral work, and leading to many deaths and disabilities [3]. Most epidemiological studies highlight the strong underestimation of incidence and mortality largely because of the complex treatment-seeking behavior of the patients [3, 4]. Snakebite management combines symptomatic and etiological treatment with antivenom [5]. Access to antivenoms is limited in low-income countries for many reasons, including the cost of products and poverty of the majority of patients [6]. Consequently, the population is turning to traditional medicine [7-9] which is a major cause of treatment delay, in addition to poor accessibility of health centers $[3,6]$.

Ethiopia is located in the horn of Africa bordering Eritrea, Djibouti, Somalia, Kenya, South Sudan and Republic of Sudan (Figure 1). According to the United Nations, the population of Ethiopia is estimated at 108 million [10], and comprised of over
80 different ethnic groups. More than $80 \%$ of the population reside in rural areas depending on agriculture resources.

There are more than 98 species of snakes, of which 22 are venomous. Most of them are found at altitudes ranging from 500 to $1,000 \mathrm{~m}$ above sea level and are dominated by savanna and desert species [11]. As in most SSA countries, snakebite incidence in Ethiopia is not known accurately due to the lack of case reporting and specific epidemiological studies [3]. However, 949 cases of snakebites were reported in approximately one year from 76 (1\%) health facilities in the country [12]. They were able to assess areas of highest incidence particularly in the Oromia, Somali, and Tigray regions. Demographic characteristics were similar to those reported in SSA countries [3]. In these regions, the sex ratio was 2 to 3 (men to women). The population at risk consisted mainly of farmers aged 16-45. The authors noted the lack of antivenom and appropriate documentation in most centers to address this problem. The few published clinical studies $[13,14]$ have reported high case fatality rates $(15-25 \%)$ in the absence of appropriate treatment. Hemorrhaging and

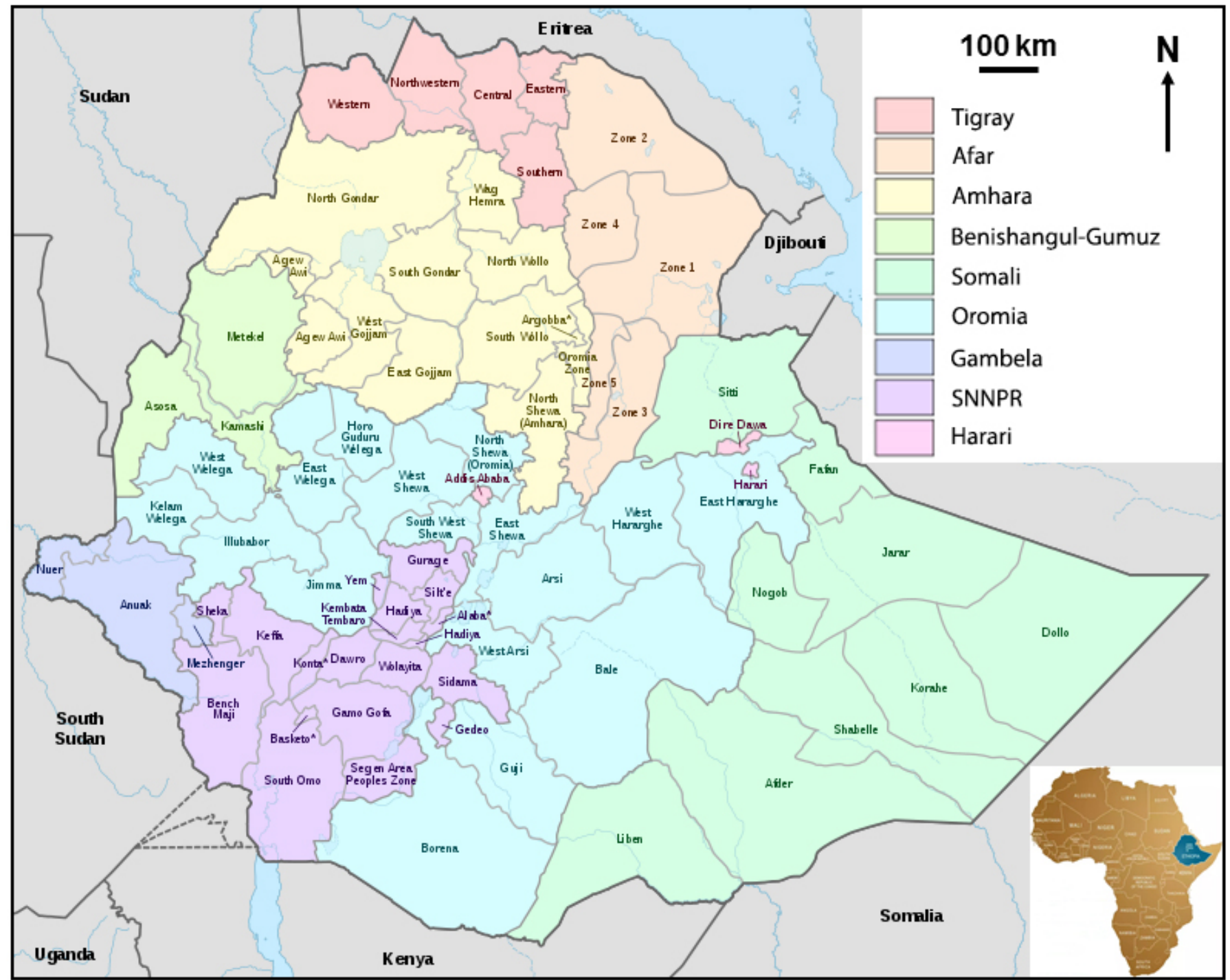

Figure 1. Map showing the geographical location of Ethiopia (modified from https://commons.wikimedia.org/wiki/File:Map_of_zones_of_Ethiopia.svg). SNNPR: Southern Nations Nationalities and People's Region. 
necrosis were common and presentation delay exceeded 12 hours in most cases. Similar to most SSA countries, most victims attended traditional healers and came to health centers when the symptoms worsened.

Interestingly, research studies on medicinal plants and traditional ethnomedicine are highly advanced in Ethiopia. Therefore, the main objective of this study is to review information on the traditional medicinal plants employed to treat snakebites in Ethiopia. This study aims to identify plants that would enhance or improve the treatment of envenomations in rural health centers based on properties that have been described in experimental studies. In addition, a comparison with the observations made in other countries would make it possible to identify the plants that are eligible for snakebite treatment [15].

\section{Techniques for data collection}

The authors reviewed scientific papers and theses from Medline, Science Digest, Google Scholar and Access to Global Online Research in Agriculture (AGORA) websites using keywords 'traditional medicinal plants', 'snakebite' and 'Ethiopia'. Available literature studies were selected based on: (i) reports written in English or French, (ii) articles for which the full texts were available, (iii) publications that present first-hand ethnobotanical information, and (iv) plants with full scientific name (describing the species names as well). A second selection of the first set of documents has been made on the basis of literature reports addressing snakebite in Ethiopia.

All relevant data on each plant species were noted: habit, part(s) used, modes of preparation and administration, and miscellaneous additive comments on the plant utilizations. In the case of discrepancies of plant habit between two reports, the higher growth form of the species was selected and respectively categorized. This was particularly the case when the difference was between "grass" and "shrub" (habit "shrub" was preferred) or between "shrub" and "tree" (we retained tree), etc. In the absence of growth habit, species authority or family names, the Flora of Ethiopia, Global Plants on JSTOR, a digital library [16], Kyalangalilwa et al. [17], Flora of Zimbabwe [18] and the plant list [19] were consulted. Finally, each dataset was prepared in an Excel $^{\circ}$ spreadsheet with botanical and family names, growth form or habit, plant part(s) used, mode of preparation, route of administration and miscellaneous information. Analysis was performed using Excel ${ }^{\circ}$ and maps were adapted from Wikipedia and Creative Commons [20].

The authors found 67 papers, articles, theses or dissertations on the use of plants in traditional human or veterinary medicine in Ethiopia that have been mentioned for the treatment of snakebites.

Studies were carried out in all regions except in the area administered by the city of Addis Ababa. Most studies were carried out in Oromia, Tigray, Amhara, Afar and Southern Nations Nationalities and People's Region (SNNPR) regional states (Figure 2).

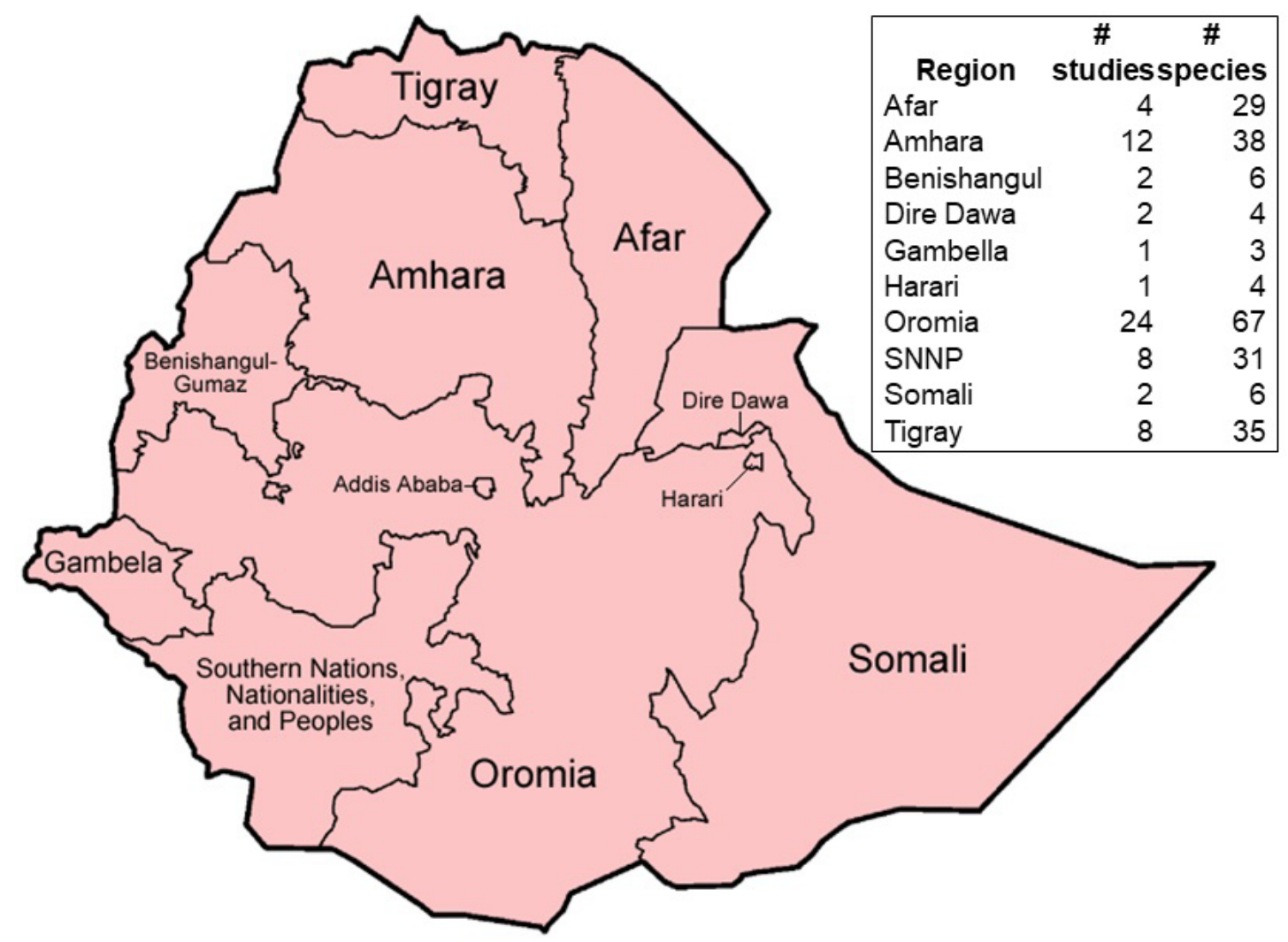

Figure 2. Regional distribution in Ethiopia of studies and ethnomedicinal plants used against snakebites (modified after https://commons.wikimedia.org/wiki/ File:Map_of_zones_of_Ethiopia.svg). 


\section{Major families of traditional medicinal plants used against snakebites}

From 295 citations of plants used for the treatment of snakebites, 184 species were identified in 67 families (Additional file 1). The distribution of the number of species per family showed that three of them had at least 15 species used against snakebites: Fabaceae, Solanaceae and Vitaceae with 29, 22 and 15 species, respectively.

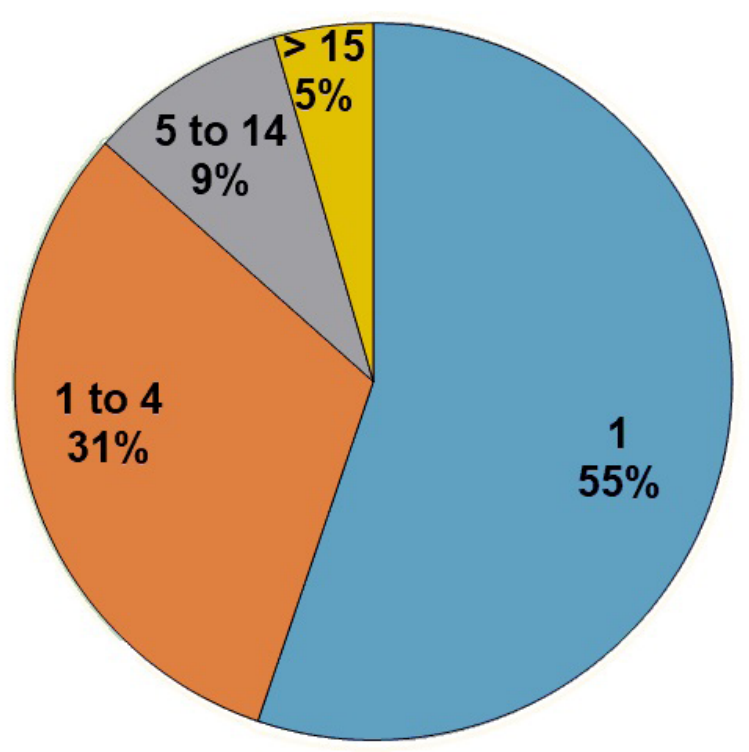

Figure 3. Distribution of ethnomedicinal plant species according to family.
Six families had 5 to 14 species and 58 fewer than five species (Figure 3). Most species were listed once (143 i.e., 78\%) or twice (23 or $13 \%$ ), while $18(9 \%)$ were cited more than twice (Figure 4, Table 1). Most species were used against snakebites in only one region of Ethiopia (144 species, 84\%). However, eight species (3\%) were used in three distinct regions (Figure 5, Table 2). The proportion of plant species employed to prevent or treat snakebites ranged from 1 to $12 \%$ in most studies (Table 3).

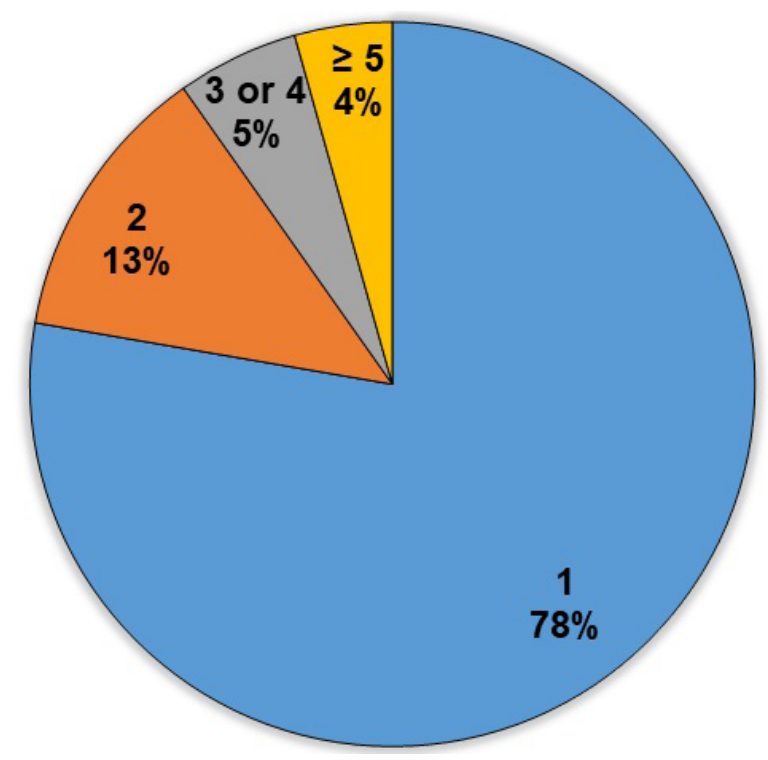

Figure 4. Number of ethnomedicinal plant species mentioned in selected literature references.

Table 1. List of the most cited ethnomedicinal plant species in Ethiopian studies.

\begin{tabular}{lcc}
\hline Species & Number of citations & References \\
\hline Nicotiana tabacum & 6 & {$[48,50,52,126,132,139]$} \\
Solanum incanum & 9 & {$[47,90,108,119,120,131,132,143,144]$} \\
Carissa spinarum & 7 & {$[46,90,93,109,110,112,118]$} \\
Calpurnia aurea & 6 & {$[52,91,103,120,134,135]$} \\
Croton macrostachyus & 6 & {$[46,107,121,123,129,130]$} \\
Cynodon dactylon & 6 & {$[46,107,120,131,132,134]$} \\
Cyphostemma adenocaule & 4 & {$[50,98,99,140]$} \\
Cyphostemma junceum & 5 & {$[54,98,99,117,118]$} \\
Plumbago zeylanica & 4 & {$[93,109,117,118]$} \\
Polygala abyssinica & 4 & {$[50,90,98,102]$} \\
Verbena officinalis & 4 & {$[50,104,117,118]$} \\
Commiphora myrrha & 2 & {$[125,126]$} \\
Echidnopsis dammaniana & 3 & {$[97,115,116]$} \\
Euclea racemosa & 3 & {$[97,98,99]$} \\
Gossypium herbaceum & 3 & {$[50,117,118]$} \\
Seddera hirsuta & 2 & {$[94,95]$} \\
Stereospermum kunthianum & 3 & {$[53,107,120]$} \\
Vernonia adoensis & 3 & {$[54,107,123]$} \\
\hline
\end{tabular}




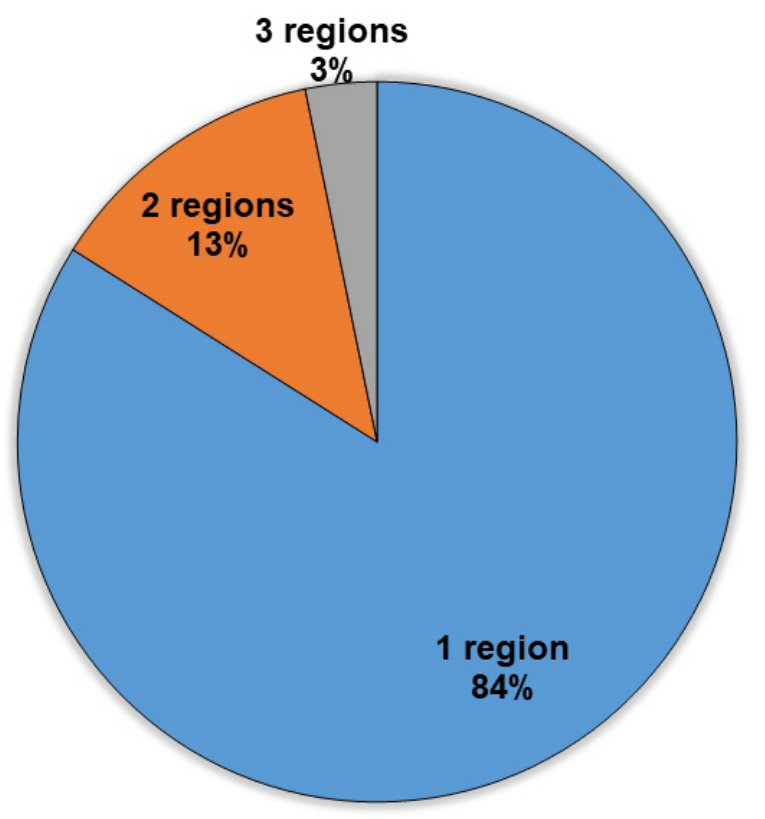

Figure 5. Number of regions sharing each ethnomedicinal plant in Ethiopia.
Figure 6 shows the distribution of plants according to their habit. The majority of species were small (herb, shrub or climber), while $23 \%$ were trees. In half of the cases, the roots were used alone or in combination with another part of the plant. Leaves accounted for more than a quarter of uses while other parts of the plant accounted for less than $10 \%$ each, most often in association with other parts (Figure 7). The mode of preparation varied according to the plant, authors, traditional healers and regions. The oral route was most frequently used followed by local application (Figure 8).

Medicinal plants are an alternative form of medication utilized by most rural communities around the world. They largely rely on the support of traditional healers that prescribe these medicinal plants for various ailments [21-24]. In addition to large-size molecules (fatty acids, glucosides and peptides) acting as energy reserves or metabolic precursors, low-molecular-weight compounds protect plants from their environment. They present intense and polyvalent biological activities resulting in various pharmacological effects [25]. In addition, a reduction in snakebite risk is achieved by repulsing snakes either by fumigation or by growing repellent plants around houses, such as Nicotiana tabacum and Datura metel [26].

Table 2. List and regional distribution of ethnomedicinal plant species used for snakebite treatment present in at least three regions of Ethiopia.

\begin{tabular}{|c|c|c|c|c|c|c|c|c|c|}
\hline Species & Amhara & Somali & Oromia & Tigray & Afar & SNNPR & Harari & Gambella & Benishangul \\
\hline Carissa spinarum & $x$ & $x$ & $x$ & $x$ & $x$ & & & & \\
\hline Solanum incanum & & $x$ & $x$ & $x$ & $x$ & $x$ & & & \\
\hline Calpurinia aurea & & & $x$ & & $x$ & $x$ & $x$ & & \\
\hline Croton acrostachyus & $x$ & & $x$ & $x$ & & & & & $x$ \\
\hline Cucumis dipsaceus & & & $x$ & $x$ & $x$ & & & & $x$ \\
\hline Cucumis ficifolius & & & $x$ & $x$ & $x$ & $x$ & & & \\
\hline Nicotiana tabacum & & & $x$ & $x$ & $x$ & $x$ & & & \\
\hline Plumbago zeylanica & $x$ & & $x$ & $x$ & $x$ & & & & \\
\hline Silene macrosolen & $x$ & & & $x$ & $x$ & & $x$ & & \\
\hline Cynodon dactylon & & & $x$ & $x$ & & $x$ & & & \\
\hline Cyphostema adenocaule & & & $x$ & $x$ & $x$ & & & & \\
\hline Echidnopsis dammaniana & & & $X$ & $x$ & $x$ & & & & \\
\hline Euclea racemosa & & & $x$ & $x$ & $x$ & & & & \\
\hline Jasminum abyssinicum & $x$ & & & & $x$ & $x$ & & & \\
\hline Leonotis ocymifolia & $x$ & & $x$ & & $x$ & & & & \\
\hline Olea europaea & $x$ & & $x$ & & $x$ & & & & \\
\hline Rhus natalensis & $x$ & & $x$ & & $x$ & & & & \\
\hline Senna obtusifolia & & & $x$ & & $x$ & $x$ & & & \\
\hline $\begin{array}{l}\text { Stereospermum } \\
\text { kunthianum }\end{array}$ & $x$ & & $x$ & & $x$ & & & & \\
\hline Verbena officinalis & & & $x$ & $x$ & $x$ & & & & \\
\hline Withania somnifera & & & $x$ & & $x$ & & & $x$ & \\
\hline
\end{tabular}


Table 3. Number of ethnomedicinal plant species used against snakebites (preventive and curative) in Ethiopia and some sub-Saharan African countries.

\begin{tabular}{|c|c|c|c|c|}
\hline Country & Number of families & Number of Species & Used for snakebites & References \\
\hline Ethiopia & 57 & 122 & $2(2 \%)$ & {$[111]$} \\
\hline Ethiopia & 31 & 49 & 0 & [146] \\
\hline Ethiopia & 49 & 82 & $3(4 \%)$ & [134] \\
\hline Ethiopia & 46 & 75 & $4(5 \%)$ & [120] \\
\hline Ethiopia & 33 & 38 & $2(5 \%)$ & [129] \\
\hline Ethiopia & 33 & 53 & $3(6 \%)$ & {$[40]$} \\
\hline Ethiopia & 31 & 62 & $6(10 \%)$ & [133] \\
\hline Ethiopia & 47 & 120 & $5(4 \%)$ & {$[91]$} \\
\hline Ethiopia & 29 & 43 & $1(2 \%)$ & {$[122]$} \\
\hline Ethiopia & 23 & 34 & 0 & [148] \\
\hline Ethiopia & 23 & 42 & $1(2 \%)$ & {$[125]$} \\
\hline Ethiopia & 43 & 81 & $3(4 \%)$ & [139] \\
\hline Ethiopia & 64 & 135 & 7 (5\%) & [93] \\
\hline Ethiopia & 67 & 163 & $10(6 \%)$ & {$[107]$} \\
\hline Ethiopia & 51 & 87 & $10(11 \%)$ & [132] \\
\hline Ethiopia & 65 & 155 & $11(7 \%)$ & [90] \\
\hline Ethiopia & 46 & 106 & $5(5 \%)$ & [105] \\
\hline Ethiopia & 23 & 33 & $3(9 \%)$ & {$[47]$} \\
\hline Ethiopia & 23 & 49 & $1(2 \%)$ & [92] \\
\hline Ethiopia & 48 & 76 & $1(1 \%)$ & {$[124]$} \\
\hline Ethiopia & 34 & 35 & 0 & [149] \\
\hline Ethiopia & 27 & 51 & $2(4 \%)$ & {$[121]$} \\
\hline Ethiopia & 26 & 34 & 0 & {$[150]$} \\
\hline Ethiopia & 47 & 115 & $12(10 \%)$ & [53] \\
\hline Ethiopia & 27 & 34 & $1(3 \%)$ & [127] \\
\hline Ethiopia & 20 & 30 & $1(3 \%)$ & [116] \\
\hline Ethiopia & 54 & 131 & $4(3 \%)$ & {$[140]$} \\
\hline Ethiopia & 26 & 42 & 0 & {$[151]$} \\
\hline Ethiopia & 49 & 128 & 7 (5\%) & [109] \\
\hline Ethiopia & 68 & 213 & $3(1 \%)$ & {$[126]$} \\
\hline Ethiopia & 50 & 85 & $6(7 \%)$ & [48] \\
\hline Ethiopia & 62 & 147 & $6(4 \%)$ & {$[131]$} \\
\hline Ethiopia & 48 & 54 & $2(4 \%)$ & [141] \\
\hline
\end{tabular}


Table 3. Cont.

\begin{tabular}{|c|c|c|c|c|}
\hline Country & Number of families & Number of Species & Used for snakebites & References \\
\hline Ethiopia & 74 & 230 & 0 & {$[152]$} \\
\hline Ethiopia & 71 & 135 & 1 & {$[103]$} \\
\hline Ethiopia & 59 & 145 & $6(4 \%)$ & {$[46]$} \\
\hline Ethiopia & 56 & 126 & $5(4 \%)$ & {$[52]$} \\
\hline Ethiopia & 58 & 101 & $5(5 \%)$ & {$[54]$} \\
\hline Ethiopia & 29 & 60 & $7(12 \%)$ & [123] \\
\hline Ethiopia & 18 & 31 & $1(3 \%)$ & {$[101]$} \\
\hline Ethiopia & 28 & 58 & $2(3 \%)$ & {$[102]$} \\
\hline Ethiopia & 57 & 133 & $3(2 \%)$ & {$[112]$} \\
\hline Ethiopia & 18 & 70 & $14(20 \%)$ & [94] \\
\hline Ethiopia & 53 & 114 & $10(9 \%)$ & [98] \\
\hline Ethiopia & 27 & 50 & $6(12 \%)$ & [99] \\
\hline Ethiopia & 40 & 60 & $3(5 \%)$ & [110] \\
\hline Ethiopia & 42 & 67 & $5(7 \%)$ & [118] \\
\hline Ethiopia & 51 & 80 & $6(8 \%)$ & [113] \\
\hline Ethiopia & 40 & 57 & $2(4 \%)$ & [138] \\
\hline Ethiopia & 33 & 91 & $10(11 \%)$ & {$[104]$} \\
\hline Ethiopia & 46 & 71 & 0 & [153] \\
\hline Benin & 69 & 114 & 0 & [155] \\
\hline Cameroon & 26 & 39 & $2(5 \%)$ & [29] \\
\hline Chad & 19 & 38 & $4(11 \%)$ & [156] \\
\hline Djibouti & 40 & 91 & $6(7 \%)$ & {$[27]$} \\
\hline Eritrea & $?$ & 256 & $15(6 \%)$ & [157] \\
\hline Eritrea & 27 & 55 & 0 & [158] \\
\hline Kenya & 26 & 48 & 0 & [159] \\
\hline Nigeria & 95 & 325 & $9(3 \%)$ & {$[26]$} \\
\hline Soudan & 31 & 53 & $2(4 \%)$ & {$[28]$} \\
\hline South Africa & 42 & 82 & $2(2 \%)$ & {$[160]$} \\
\hline
\end{tabular}

Several traditional medicinal plant families were reported to be efficacious at treating or avoiding snakebite in different countries. Some of these included: Aloaceae, Aristolochiaceae, Fabaceae, Lamiaceae and Rhamnaceae in Djibouti [27], Caesalpiniaceae and Mimosaceae in Sudan [28], Acanthaceae,
Amaranthaceae, Asclepiadaceae, Burseraceae, Commelinaceae, Lamiaceae and Loganiaceae in Nigeria [26], and Melastomataceae and Menispermaceae in Cameroon [29]. The most commonly encountered families listed were: Acanthaceae, Amaranthaceae, Amaryllidaceae, Compositae, Celastraceae, Capparaceae, 


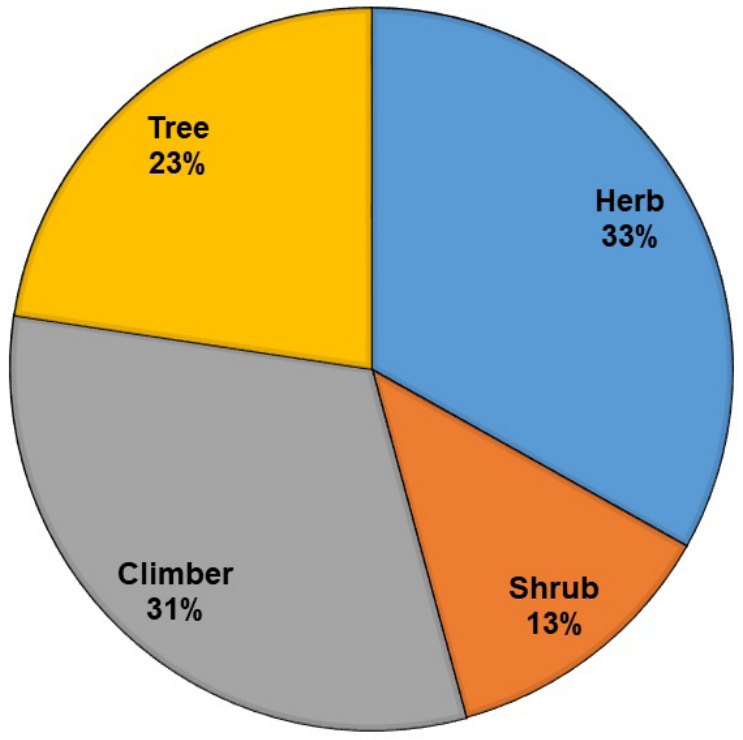

Figure 6. Distribution of ethnomedicinal plant habits used against snakebite in Ethiopia.

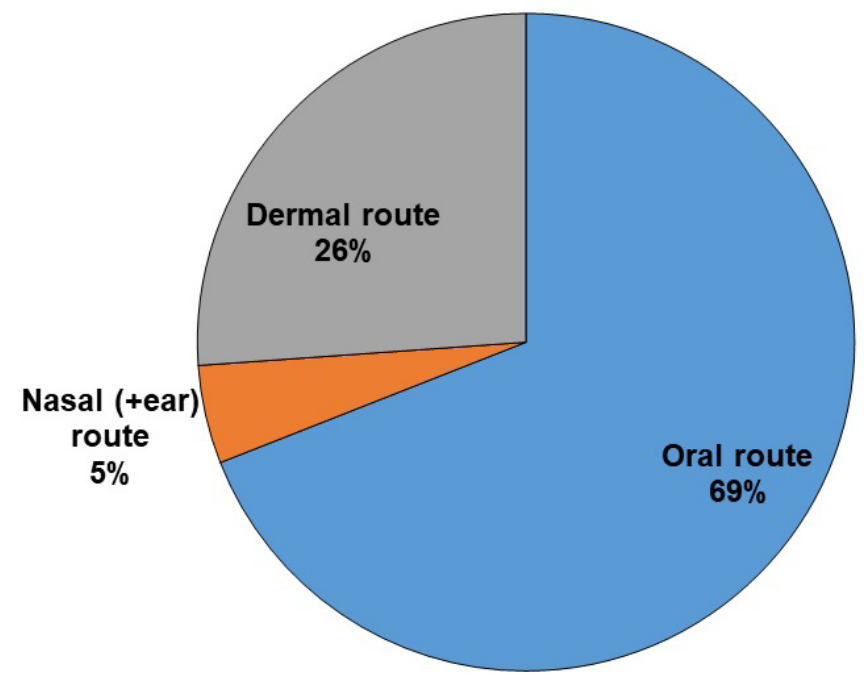

Figure 8. Administration routes used for ethnomedicinal plants used against snakebite in Ethiopia.

Burseraceae, Brassicaceae, Boraginaceae, Aristolochiaceae, Araceae, and Apocynaceae [30]. Acanthaceae, Amaranthaceae, Apocynaceae, Araceae, Asteraceae, Caesalpiniaceae, Cucurbitaceae, Euphorbiaceae, Fabaceae, Lameaceae, Moraceae, Rubiaceae, Rutaceae and Zingiberaceae were mentioned in India [31] as important families of medicinal plants for snakebites or snake repellent, whereas families such as Apocynaceae, Araceae, Aristolochiaceae, Asteraceae, Convolvulaceae, Fabaceae, Passifloraceae, Piperaceae, Polygonaceae, Rubiaceae and Solanaceae were reported in Central America [32]. Two families commonly recognized for their medicinal values in Ethiopia were described in other countries: Fabaceae in Djibouti, India and Central America; and Lamiaceae in Djibouti, Nigeria and India.

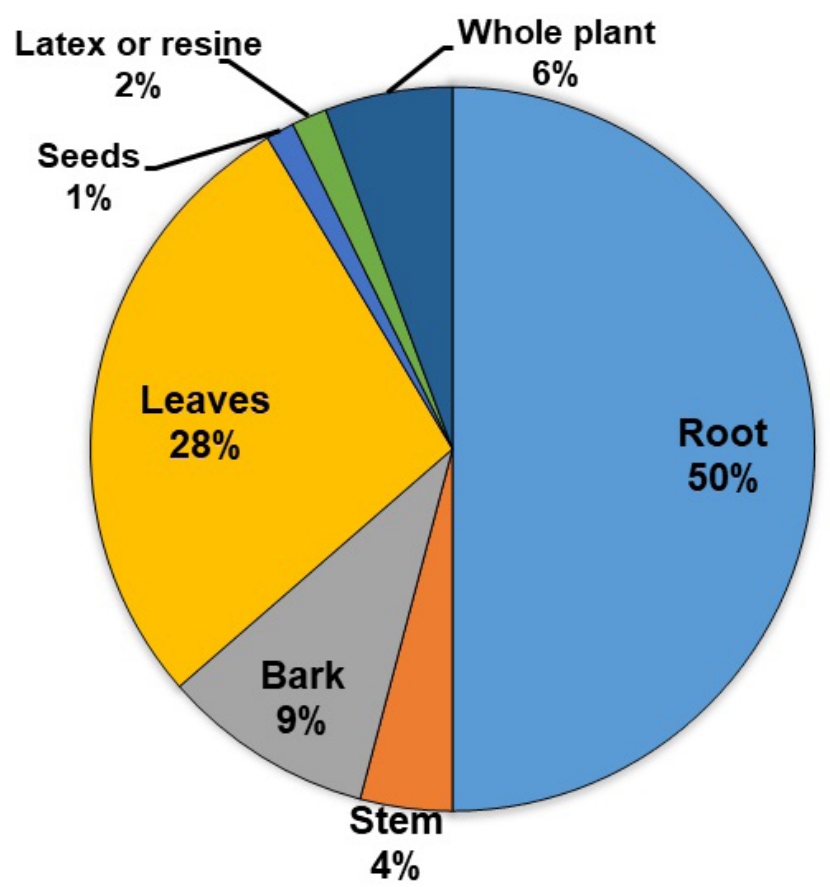

Figure 7. Ethnomedicinal plant parts used against snakebite in Ethiopia.

In SSA, snakebite patients primarily consult traditional healers [3]. Several reasons explain this treatment-seeking behavior [3, $4,8]$. The main causes of delay until hospital presentation or rejection of modern medicine have been highlighted: (i) popular beliefs, (ii) impression of relative effectiveness of traditional treatments due to the fact that the majority of bites are not fatal and that many of them are not followed by envenomation, (iii) greater logistical and financial accessibility of traditional medicine, and (iv) inadequate management of snakebites in health centers due to a lack of drugs or properly trained staff $[3,4,6,8,33]$.

In Ethiopia, 184 plant species from 67 families (more than a third belonging to Fabaceae, Solanaceae or Vitaceae) have been reported. The comparison between Ethiopian studies and those in other SSA countries is displayed in Table 3 just as an indication because the search for studies performed in countries other than Ethiopia was not conducted with the same objective of completeness. The high proportion of plants used against snakes and snakebites is probably due to the high incidence of snakebites $[1,2]$ and by the position of snakes in traditional cultures [34].

\section{Factors that determine the choice of traditional medicinal plants}

The choice of the plants by traditional healers depends on complex mechanisms [35]. The smell and appearance of the plant, such as the presence of aerial roots reminiscent of the snake's body [36-38], folklore legends [39], observation and empiricism that support the curative action of plants [36] have led traditional medicine to preferentially use some of medicinal plants to 
treat snakebites. Information circulates mainly vertically and endogenously. Training is shared within the community between experienced traditional healers and their students, who are chosen mainly among male children within their own family [40]. Comparison of the use of plants against snakebites in two distinct ethnic groups in Kenya showed that the choice depended on independent cultural origins [41]. This could explain why few plant species are used against snakebites simultaneously in several regions (Figure 5, Table 2). Another reason could be that analog active substances are widely distributed among species of the same family, or even close families, which constitutes a redundancy by allowing a use of different plants for the same disease, or of the same plant for distinct ailments, considering symptomatic treatments.

For example, Securidaca longepedunculata (Polygalaceae) is one of the main herbs used as an anti-inflammatory, analgesic and specific antidote for snakebites in many West African communities [35, 36, 42-45]. In Ethiopia, the species is widely traded [46] due to environmental constraints, deforestation and other uses that endanger it [47-50]. In other parts of SSA, S. longepedunculata is used against evil eye and/or as a psychotropic [28, 45, 51-55]. However, although $S$. longepedunculata is frequently used in Ethiopia as anti-inflammatory or analgesic [46, 48, 51], it is likely that traditional practitioners do not utilize this plant for symptomatic treatment of snakebite. As a result, it may be interesting to search for plants used against snakebites in several communities, assuming that this convergence reflects widely recognized efficacy and, secondly, identify plants belonging to the same family that contain substances of interest [15].

In traditional medicine, the use of plants is strongly linked to spiritual and religious practices associating the administration of the plant or its extract with incantations, offerings, ritual gestures or prayers [36]. These practices are mentioned in several studies of our series but never detailed. Their psychosomatic role is nevertheless considered essential, especially in relation to the anxiety of the patient and his entourage, and an important asset for healing.

\section{Plant parts, preparation methods and application mode of remedies}

Roots and leaves are used in three quarters of snakebite preparations. On the other hand, plant embryonic forms, such as the seed, bud or bulb (gemmotherapy) which concentrate certain substances of the plant [36], remain exceptionally prescribed, e.g. six times in our series (Additional file 1).

Plant preparation is an important aspect. The extraction of active substances depends on the part of the plant or the solvent used, and influences the efficacy and toxicity. The aqueous extract of Nicotiana rustica (Solanaceae) had no significant effect on the proteases of Naja nigricollis (Elapidae) venom whereas the ethanolic extract completely inhibits its proteolytic activity [56]. We have collected little precise information on the preparation of plants or extracts before their administration. In Ethiopia, aqueous extractions are the most common. Electuaries made with butter or honey are sometimes mentioned, but alcoholic solutions are uncommon. With regard to a medical emergency such as snakebite, many traditional healers prefer ready-to-use stable preparations such as powders, paste or dried plants [36].

External uses represented one-third of uses. Internal uses were mainly achieved by oral administration (70\%). Endermic routes, obtained by rubbing the plant on the skin or by contact with a mucous membrane, particularly the mouth or the nose to allow rapid diffusion, were observed in nearly $10 \%$. The intra-rectal route (enema), which produces results similar to parenteral injection of most micromolecules, was not mentioned in our series. The dosage is rarely specified because it is not a factor considered by traditional healers as decisive, apart from mystical considerations $[36,38,57]$.

\section{Health effects of snakebite and chemical composition of venom}

Snakebites cause an inflammatory syndrome associating pain, edema, hemorrhaging and necrosis by enzymatic digestion of the tissues and lack of vascularization, or neuromuscular paralysis by blocking nerve impulse [58]. These symptoms are often complicated by failure of major organs (heart, lung, kidney, brain, etc.). Snake venoms are essentially composed of low-molecular-weight toxins acting on a membrane receptor, and enzymes that hydrolyze various types of molecules. African Viperidae venoms are particularly rich in enzymes responsible for inflammation, hemorrhaging and necrosis. Serine proteases (SP) activate coagulation and lead to the consumption of coagulation factors until they are depleted, resulting in bleedings. Hyaluronidase promotes the spreading of venom in the body. Zn-Metalloproteinases (MP) hydrolyze vascular endothelium causing extravasation of blood from the vessels. L-amino acid oxidase (L-AAO) is responsible for apoptosis and cytotoxicity, and acts on platelet aggregation. Phospholipases $\mathrm{A}_{2}\left(\mathrm{PLA}_{2} \mathrm{~s}\right)$, according to their structure, are responsible for several toxic actions: (i) activation of factor $\mathrm{X}$ of blood coagulation in which the calcium ions intervene, causing consumption of coagulation factors such as SP, (ii) hydrolysis of platelet membrane, preventing blood clot formation, and iii) activation of inflammation mediators.

African Elapidae have venoms composed of (i) cytotoxins (CT), (ii) neurotoxins (NT), and (iii) enzymes, particularly $\mathrm{PLA}_{2}$ s. CT target membrane receptors, destroying the cell, whereas NT block cholinergic receptors, causing paralysis of respiratory muscles. $\mathrm{PLA}_{2} \mathrm{~s}$ activate inflammation mediators and destroy muscles, leading to paralysis and necrosis.

Plants present two modes of action: symptomatic effects and antidotes [35]. Symptomatic treatment aims at alleviating or eliminating pain or edema, as well as hemorrhaging and necrosis. This action results from indirect intervention in the pathologic mechanisms. In contrast, antidotes inhibit venom action. Plants 
can also act preventively against the deleterious effects of venom when the plant is administered prior to the bite [25].

Generally, the efficacy of plant extracts is measured in vivo by their capacity to neutralize the lethal dose $50 \%\left(\mathrm{LD}_{50}\right)$ of the venom in mice. Some tests are performed in vivo or in vitro on specific toxic activities (hemorrhaging, necrosis, neurotoxicity, etc.) using models focused on more accurate biological targets [58].

\section{Effects of plant extraction method on the efficacy of plant antivenom mechanism}

Many plants present a significant antivenom effect, although the mechanism is still poorly documented. Methanol extract of Crinum jagus (Amaryllidaceae), administered orally or intraperitoneally after incubation with the venom or separately, protected mice against an injection of venom from Echis ocellatus, Bitis arietans (Viperidae) and Naja nigricolis [59]. The methanol extract from leaves of Guiera senegalensis (Combretaceae) reduced mortality of mice inoculated with venom of Echis ocellatus and Naja nigricollis [60]. The ethanol extract of Diodia scandens (Rubiaceae) reduced the systemic toxicity of Echis carinatus venom [61]. Neurotoxic effects of Elapidae venom and hemorrhaging due to Viperidae venom were neutralized by aqueous and methanol extracts of Parkia biglobosa (Mimosaceae) [62]. However, the results were not confirmed in vivo in mice whose mortality was not reduced but only delayed. A low neutralization of venoms of Dendroaspis jamesoni (Elapidae) and Echis ocellatus was observed in mice after oral administration of Schumanniophyton magnificum (Rubiaceae), Bidens pilosa (Asteraceae), and Garcinia lucida (Clusiaceae) [43]. The methanol extract from Boswellia dalzielli (Burseraceae) partially neutralized the toxic effect of Echis ocellatus venom in previously envenomed rats [63].

Molander et al. [64] studied 226 extracts from 94 SSA plants likely to inhibit the enzymatic activities (hyaluronidase, $\mathrm{PLA}_{2}$ and proteases) of Bitis arietans and Naja nigricollis venoms. Fabaceae, Anacardiaceae and Malvaceae contain the largest number of species that neutralize snake venom enzymes. The aqueous extracts of Pupalia lappacea (Amaranthaceae), Combretum molle (Combretaceae), Strychnos innocua (Laganiaceae) and Grewia mollis (Tiliaceae), and ethanol extracts of Lannea acida (Anacardiaceae) and Bauhinia thonningii (Fabaceae) - even after elimination of polyphenols, whose action is nonspecific retained an inhibitory activity of hyaluronidase and proteases. The aqueous extract of some Urticaceae, Asteraceae or Rubiaceae inhibited the production of mediators involved in the local and systemic inflammatory process induced by venoms, notably by inhibition of prostaglandin synthesis as effectively as indomethacin or dexamethasone [44, 65-68].

PLA inhibitors have been among the most studied [69]. Many phenolic compounds inhibit $\mathrm{PLA}_{2}$ s, and include: (i) flavonoids, coumestans, alkaloids and various carboxylic acids such as acetylsalicylic, aristolochic, chlorogenic and caffeic acids, (ii) steroids (sterols and cholesterol) and (iii) terpenoids which include oleanolic acid and lupeol $[69,70]$.

Schumanniophyton magnificum, Eclipta prostrata (Asteraceae) and Aristolochia shimadai (Aristolochiaceae) extracts inhibited $\mathrm{PLA}_{2}$ venom activity [71]. The ethanol extract of Anacardium occidentale (Anacardiaceae) neutralized the enzymes ( $\mathrm{PLA}_{2}$, protease and hyaluronidase) from Daboia russelii venom (Viperidae) and inhibited venom-induced edema, hemorrhaging, myotoxicity and lethality [72]. The methanol extract of Leucas asperas (Lamiaceae) neutralized the proteases and hyaluronidase of the Naja naja venom (Elapidae), as well as its hemolytic effects but did not inhibit PLA 2 activity [73]. Pinostrobin, a flavonoid isolated from the dichloromethane extract of Renealmia alpinia (Zingiberaceae), significantly inhibited the enzymatic and hemolytic activities of Bothrops asper (Viperidae) and attenuated tissue damage and hemorrhagic effects with a documented peripheral and anti-inflammatory analgesic action [74, 75].

Vegetal substances act by different mechanisms on the venom proteins, leading to partial or total neutralization of their activities. Antivenom may act by different mechanisms to neutralize the venom proteins: (i) precipitation, (ii) structural modification, (iii) alteration of the function, particularly by chelation of the metal ion necessary for the activity, (iv) destruction, (v) competition or antagonism, in particular by steric hindrance, taking its place - or a nearby place - on the receptor of the toxin or the enzyme.

The inhibition of the hemorrhagic effect of the venom of Bothrops jararaca (Viperidae) by certain plants is generally accomplished by inactivation of the venom enzymes without structural degradation, as confirmed by the electrophoresis of the venom proteins after incubation of the plant extract with the venom [76]. Black tea melanin contains a polyphenol that counteracts the toxicity of Viperidae venoms by calcium chelation and nonspecific inhibition of $\mathrm{PLA}_{2}$ s from venoms [77]. Some organic plants extracts, particularly Euphorbiaceae, inhibit Viperidae MPs responsible for hemorrhaging, probably by chelation of the zinc ion necessary for catalytic activity [76, 78].

The aqueous extract of Aristolochia indica root (Aristolochiaceae) partially destroyed the proteins of the venom of Daboia russelii (Viperidae), probably through the action of aristolochic acid. This alkaloid isolated from Aristolochia species is a noncompetitive inhibitor of venom enzymes [79]. The interaction between aristolochic acid and $\mathrm{PLA}_{2} \mathrm{~s}$ caused a modification of the secondary structure of the protein without detectable change in its tertiary structure $[80,81]$.

The methanol extract of Schumanniophyton magnificum inactivated previously administered venom of Naja melanoleuca [82]. Schumanniofoside probably oxidized NT disulfide bridges, which are essential for the toxicity. A similar effect has been observed against cobra venom CT structurally analogous to the NT [83].

The protective effect that results from an administration of a substance prior to the envenomation depends on molecular interactions between the plant substance and venom action 
site. For example, seven very young twigs of Annona senegalensis (Annonaceae) and seven seeds of Aframomum melegueta (Zingiberaceae) are eaten to avoid snakebites [26]. In addition to the mystical side of the preparation and the symbolic significance of the number 7 , the antivenom effect has been demonstrated [ 84 , 85]. The aqueous extract of Annona senegalensis, deposited on the nerve-muscle preparation of the gastrocnemius of amphibian before the venom of Bitis arietans, showed a significantly higher antivenom effect than the mixture of the extract with the venom, suggesting a preventive rather than curative efficacy. However, the mechanism of this effect remains unclear because B. arietans venom is known to be proteolytic and devoid of neurotoxicity, at least in mammals. Similarly, Securidaca longepedunculata extract antagonized the paralyzing action of Naja nigricollis venom on an isolated amphibian nerve-muscle preparation in a dose-dependent manner [42]. The authors hypothesized that S. longepedunculata extract binds the vicinity of the cholinergic receptor without modifying its activity but preventing the paralysis due to NT [42, 43, 58].

The aqueous extract of lectin-bearing Mucuna pruriens seeds (Fabaceae), inoculated in mice 24 hours before the administration of Echis carinatus venom protected the mice, whereas the incubation of the venom with the extract did not exert a neutralizing effect [86]. The lectin has a conserved domain similar to an epitope of venom $\mathrm{PLA}_{2}$ that binds to factor $\mathrm{X}$. The lectin binds to factor $\mathrm{X}$ by this epitope, preventing PLA from binding to a coagulation factor.

However, ELISA and immunotransfer studies have shown cross-reactions between rabbit IgG against plant extract and snake venoms, the neutralization of which was specifically conferred by $M$. pruriens seed extract [87]. The results suggested that some plant proteins have common epitopes with toxins or enzymes of the venom allowing a competition with the latter that prevents their attachment to the receptors.

Finally, plants can also have an adjuvant effect on the defense mechanisms of an envenomation victim. Proteomic studies showed that aqueous extract of Mucuna pruriens (Fabaceae) caused major changes in the plasma proteome inoculated with Echis carinatus venom (Viperidae), suggesting that the systemic but nonspecific protective effect against coagulant and inflammatory activities would enable the victim to endure the critical phase of envenomation [88]. The benefits can be an increasing survival time, reduction of toxic signs, improvement of diaphragmatic contraction and inhibition of proteolysis. The cardiovascular system, in particular, is protected by the action of certain plants on blood pressure, atrial contractility and rhythm, or the prevention of endothelial damage [89].

\section{Conclusion}

Plants remain the main therapeutic remedy for sub-Saharan populations, particularly in rural areas where snakebites are common. It is therefore essential to inventory them and ensure their effectiveness. In addition, the uses of traditional medicinal plants are well recognized for their contribution to developing new drugs that assist in overcoming public health problems. Accordingly, the authors attempted to compile both published and unpublished literatures available online, although these studies were limited to fewer than 25 percent of the total districts of Ethiopia. In addition, the lowlands that are largely recognized as the biogeography of snakebites are not well addressed. However, they are highly representative of the phytopharmacopeia against snakebite in Ethiopia and could serve as a basis for further studies. Data on medicinal plants and their uses should be gathered through contextualized ethnomedical studies. Besides the need for first-hand information from the abovementioned districts, future studies need to evaluate the phytochemical constituents of most widely used medicinal plants of Ethiopia. In addition, experimental activities of a plant substance must be confirmed and validated by standardized clinical trials in humans.

\section{Acknowledgments}

AY thanks his wife Mrs. Tigist Abera, and Drs. Shiferaw Alem, Worku Zewdie and Alemu Gezahgne for their continuous encouragement during the preparation of this manuscript. The authors also appreciate all the researchers who devoted much to uncover the hidden knowledge on the medicinal plants against snakes in Ethiopia.

\section{Abbreviations}

SSA: sub-Saharan Africa; SNNPR: Southern Nations Nationalities and People's Region; SP: serine proteases; MP: metalloproteinases; L-AAO: L-amino acid oxidase; $\mathrm{PLA}_{2} \mathrm{~s}$ : phospholipases $A_{2}$; CT: cytotoxins; NT: neurotoxins; $\mathrm{LD}_{50}$ : lethal dose $50 \%$.

\section{Availability of data and material}

Not applicable.

\section{Funding}

No funding was necessary for this study.

\section{Competing interests}

The authors declare that they have no competing interest.

\section{Authors' contributions}

AY designed the study. AY and JPC collected the data and publications independently. AY drafted the manuscript, which was revised and completed by JPC. Both authors are guarantors of the study.

\section{Ethics approval and consent to participate}

Not applicable. 


\section{Consent for publication}

Not applicable.

\section{Supplementary material}

Additional file 1. Scientific name, habit, part used, method of preparation, route of administration and applications of ethnomedicinal plants employed in Ethiopia for snakebite treatment.

\section{Reference}

1. Chippaux JP. Snake-bites: appraisal of the Global situation. Bull World Health Organ. 1998;76(5):515-24.

2. Kasturiratne A, Wickremasinghe AR, de Silva N, Gunawardena NK, Pathmeswaran A, Premaratna R, et al. The global burden of snakebite: a literature analysis and modelling based on regional estimates of envenoming and deaths. PLoS Med. 2008;5(11):e218.

3. Chippaux JP. Estimate of the burden of snakebites in sub-Saharan Africa: A meta-analytic approach. Toxicon. 2011;57(4):586-99.

4. Chippaux JP. The treatment of snake bites: analysis of requirements and assessment of therapeutic efficacy in tropical Africa. In: Perspectives in molecular toxinology, Ménez A. editor. John Wiley, Sons, Ltd Chichester; 2002. p. 457-72.

5. Warrell DA. Snake bite. Lancet. 2010;375(9708):77-88.

6. Stock RP, Massougbodji A, Alagón A, Chippaux JP. Bringing antivenoms to Sub-Saharan Africa. Nat Biotechnol. 2007;25(2):173-7.

7. Snow RW, Bronzan R, Roques T, Nyamawi C, Murphy S, Marsh K. The prevalence and morbidity of snake bite and treatment-seeking behaviour among a rural Kenyan population. Ann Trop Med Parasitol. 1994;88(6):665-71.

8. Newman WJ, Moran NF, Theakston RDG, Warrell DA, Wilkinson D. Traditional treatments for snake bite in a rural African community. Ann Trop Med Parasitol. 1997;91(8):967-9.

9. Somé N, Poda JN, Guissou IP. [Epidemiology and management of snake envenomations in the Dano health district, loba province (Burkina Faso) from 1981 to 2000]. Bull Soc Pathol Exot. 2002;95(3):163-6. [Article in French].

10. https://population.un.org/wpp/. Accessed 6 Nov 2018.

11. Largen MJ, Rasmussen JB. Catalogue of the snakes of Ethiopia (Reptilia Serpentes), including identification keys. Trop Zool. 1993;6(2):313-434.

12. Aga AM, Hurisa B, Niwayesillassie B, Kebede G, Kerga S, Kebede A, et al. Epidemiological survey of snakebite in Ethiopia. Epidemiology (Sunnyvale). 2014;4:174.

13. Tameru K. Snake bite envenomation at Aysha refugee camp health center. Ethiop Med J. 2006;44(1):75-9.

14. Mekonnen D, Mitiku T, Tamir Y, Azazh A. Snake bite: case series of patients presented to Gondar University Hospital, North West Ethiopia. Ethiop Med J. 2016;54(2):83-6.

15. Molander M, Saslis-Lagoudakis CH, Jäger AK, Rønsted N. Cross-cultural comparison of medicinal floras used against snakebites. J Ethnopharmacol. 2012;139(3):863-72.

16. https://plants.jstor.org/compilation/. Accessed 6 Nov 2018.

17. Kyalangalilwa B, Boatwright JS, Daru BH, Maurin O, van der Bank M. Phylogenetic position and revised classification of Acacia s.l. (Fabaceae: Mimosoideae) in Africa, including new combinations in Vachellia and Senegalia. Bot J Linnean Soc. 2013;172(4):500-23.

18. http://www.zimbabweflora.co.zw/speciesdata/. Accessed 6 Nov 2018.

19. www.theplantlist.org/. Accessed 6 Nov 2018.

20. https://creativecommons.org/licenses/by-sa/4.0/. Accessed 6 Nov 2018.

21. Gomes A, Das R, Sarkhel S, Mishra R, Mukherjee S, Bhattacharya S, et al. Herbs and herbal constituents active against snake bite. Indian J Exp Biol. 2010;48(9):865-78.
22. Ismaila MS, Adamu SA. The impact of traditional methods of managing snake bite in humans and livestock among the Hausa-Fulani communities of Sokoto State (North-western Nigeria). J Med Plant Res. 2012;6(28):4489-93.

23. Minu V, Harsh V, Ravikant T, Paridhi J, Noopur S. Medicinal plants of chhattisgarh with anti-snake venom property. Int J Curr Pharm Rev Res. 2012;3(2):1-10.

24. Maregesi SM, Kagashe GAB, Masatu K. Ethnophamacological survey of snake bite treatment in Ukerewe Island, Tanzania. Sch Acad J Pharm. 2013;2(5):381-6.

25. Mors WB, Nascimento MC, Pereira BM, Pereira NA. Plant natural products active against snake bite--the molecular approach. Phytochemistry. 2000;55(6):627-42.

26. Abd El-Ghani M. Traditional medicinal plants of Nigeria: an overview. Agric Biol J N Am. 2016;7(5):220-47.

27. Hassan-Abdallah A, Merito A, Hassan S, Aboubaker D, Djama M, Asfaw $Z$, et al. Medicinal plants and their uses by the people in the Region of Randa, Djibouti. J Ethnopharmacol. 2013;148(2):701-13.

28. Musa SS, Abdelrasool FE, Elsheikh EA, Ahmed LAMN, Mahmoud ALE, Yagi SM. Ethnobotanical study of medicinal plants in the Blue Nile State, South-Eastern Sudan. J Med Plants Res. 2011;5(17):4287-97.

29. Ndah NR, Egbe AE, Bechem EET, Asaha S, Yengo T, Chia EL, et al. Ethnobotanical study of commonly used medicinal plants of the Takamanda Rainforest South West, Cameroon. Afr J Plant Sci. 2013;7(1): 21-34.

30. Iwu MM. Handbook of African Medicinal Plants. Boca Raton, CRC Press. Taylor and Francis Group, LLC, $2^{\text {nd }}$ ed. 2014. pp. 506.

31. Upasani SV, Beldar VG, Tatiya AU, Upasani MS, Surana SJ, Patil DS. Ethnomedicinal plants used for snakebite in India: a brief overview. Integr Med Res. 2017;6(2):114-30.

32. Giovannini P, Howes MR. Medicinal plants used to treat snakebite in Central America: Review and assessment of scientific evidence. J Ethnopharmacol. 2017;199:240-56.

33. Silveira PV, Nishioka Sde A. Venomous snake bite without clinical envenoming ('dry-bite'). A neglected problem in Brazil. Trop Geogr Med. 1995;47(2):82-5.

34. Deane JB. The worship of the serpent traced throughout the world. Rivington JG \& Rivington F, London, 1833.

35. Chippaux JP, Rakotonirina S, Dzikouk G, Nkinin S, Rakotonirina A. Connaissances actuelles et perspectives de la phytopharmacopée dans le traitement des envenimations ophidiennes. Bull Soc Herpétol Fr. 2001;97:5-17.

36. Kerharo J, Adam JG. La Pharmacopée sénégalaise traditionnelle. Plantes médicinales et toxiques. Paris: Vigot Frères. 1975.

37. Houghton PJ, Osibogun IM. Flowering plants used against snakebite. J Ethnopharmacol. 1993;39(1):1-29.

38. Lans C, Harper T, Georges K, Bridgewater E. Medicinal and ethnoveterinary remedies of hunters in Trinidad. BMC Complement Altern Med. 2001;1:10.

39. Maydell HJ. von. Arbres et arbustes du Sahel. Leurs caractéristiques et leurs utilisations. Deutche-Gesellschaft für Technische Zusammenarbeit, Eschborn; 1983.

40. d'Avigdor E, Wohlmuth H, Asfaw Z, Awas T. The current status of knowledge of herbal medicine and medicinal plants in Fiche, Ethiopia. J Ethnobiol Ethnomed. 2014;10:38.

41. Owuor BO, Kisangau DP. Kenyan medicinal plants used as antivenin: a comparison of plant usage. J Ethnobiol Ethnomed. 2006;2:7.

42. Koné PP, Chippaux JP, Tricoche R. Mécanisme d'action au niveau de la junction neuro-musculaire d'une substance antivenimeuse naturelle de la pharmacopée traditionnelle africaine (extrait de Securidaca longepedunculata). Bibliothèque numérique CAMES. 1979. http:// greenstone.lecames.org/collect/revueph1/index/assoc/HASH0110.dir/04182-184.pdf.

43. Chippaux JP, Rakotonirina VS, Rakotonirina A, Dzikouk G. Substances médicamenteuses ou végétales antagonistes du venin ou potentialisant le sérum antivenimeux. Bull Soc Pathol Exot. 1997;90(4):282-5.

44. Okoli C, Akah P, Ezugworie U. Anti-inflammatory activity of extracts of root bark of Securidaca longipedunculata Fres (Polygalaceae). Afr J Trad CAM. 2005;3(1):54-63. 
45. Keshebo DL, Choudhury MK, Dekebo AH. Investigation on toxicity, hypoglycaemia effect of the root bark of Securidaca longipedunculata Fresen (Polygalaceae) and determination of heavy metals. Ann Biol Res. 2014;5(6):15-9.

46. Maryo M, Nemomissa S, Bekele T. An ethnobotanical study of medicinal plants of the Kembatta ethnic group in Enset-based agricultural landscape of Kembatta Tembaro (KT) Zone, Southern Ethiopia. Asian J Plant Sci Res. 2015;5(7):42-61.

47. Giday M. An ethnobotanical study of medicinal plants used by the Zay people in Ethiopia. CBM:s Skriftserie. 2001;3:81-99.

48. Kumbi ET. Use and conservation of traditional medicinal plants by indigenous people in Gimbi Woreda, Western Wellega. MSc Thesis: Addis Ababa University School of Graduate Studies, 2007. https://www.google.

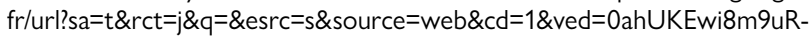
guDbAhVB7BQKHZOgAUMQFggnMAA\&url=https\%3A\%2F\%2Fwww. ephi.gov.et\%2Fimages\%2Fpictures\%2Fdownload2010\%2FTRDMED\%2FGimbi\%2520Woreda.pdf\&usg=AOvVaw1snvIXIOrkoopGMI0f48tZ; accessed June 19, 2018.

49. Mesfin F, Demissew S, Teklehaymanot T. An ethnobotanical study of medicinal plants in Wonago Woreda, SNNPR, Ethiopia. J Ethnobiol Ethnomed. 2009;5:28.

50. Araya S, Abera B, Giday M. Study of plants traditionally used in public and animal health management in Seharti Samre District, Southern Tigray, Ethiopia. J Ethnobiol Ethnomed. 2015;11:22.

51. Zenebe G, Zerihun M, Solomon Z. An ethnobotanical study of medicinal plants in Asgede Tsimbila District, Northwestern Tigray, Northern Ethiopia. Ethnobot Res Appl. 2012;10:305-20.

52. Megersa M, Asfaw Z, Kelbessa E, Beyene A, Woldeab B. An ethnobotanical study of medicinal plants in Wayu Tuka District, East Welega Zone of Oromia Regional State, West Ethiopia. J Ethnobiol Ethnomed. 2013;9(1):68.

53. Gidey M, Beyene T, Signorini MA, Bruschi P, Yirga G. Traditional medicinal plants used by Kunama ethnic group in Northern Ethiopia. J Med Plants Res. 2015;9(15):494-509.

54. Mekuanent T, Zebene A, Solomon Z. Ethnobotanical study of medicinal plants in Chilga District, Northwestern Ethiopia. J Nat Rem. 2015;15(2):88-112.

55. Wubetu M, Sintayehu M, Aeta MA, Reta H, Derebe D. Ethnobotany of medicinal plants used to treat various mental illnesses in Ethiopia: A systematic review. Asian J Plant Sci Res. 2018;8(1):9-33.

56. Ibrahim MA, Aliyu AB, Abusufiyanu A, Bashir M, Sallau AB. Inhibition of Naja nigricolis (Reinhardt) venom protease activity by Luffa egyptiaca (Mill) and Nicotiana rustica (Linn) extracts. Indian J Exp Biol. 2011;49(7):552-4.

57. Lemordant D. Contribution à l'éthnobotanique éthiopienne. J Agr Trop Bot Appl. 1971;18(4-6):155-75.

58. Chippaux JP. Snake venoms, Envenomations. Krieger Publishing Co., Malabar, FI, USA; 2006. p. 287.

59. Ode OJ, Asuzu IU. The anti-snake venom activities of the methanolic extract of the bulb of Crinum jagus (Amaryllidaceae). Toxicon. 2006;48(3):331-42.

60. Abubakar MS, Sule MI, Pateh UU, Abdurahman EM, Haruna AK, Jahun BM. In vitro snake venom detoxifying action of the leaf extract of Guiera senegalensis. J Ethnopharmacol. 2000;69(3):253-7.

61. Onuaguluchi G. Preliminary study of an extract from Diodia scandens on some toxic effects of Echis carinatus venom. J Ethnopharmacol. 1989;26(2):189-96.

62. Asuzu IU, Harvey AL. The antisnake venom activities of Parkia biglobosa (Mimosaceae) stem bark extract. Toxicon. 2003;42(7):763-8.

63. Genwa EL, Yero H. The anti-venom potential of the stem bark of Boswellia dalzielli on saw-scaled viper venom. Chem Class J. 2004:19-23.

64. Molander M, Nielsen L, Søgaard S, Staerk D, Rønsted N, Diallo D, et al. Hyaluronidase, phospholipase $A_{2}$ and protease inhibitory activity of plants used in traditional treatment of snakebite-induced tissue necrosis in Mali, DR Congo and South Africa. J Ethnopharmacol. 2014;157:171-80.

65. Ruppelt BM, Pereira EFR, Gonçalves LC, Pereira NA. Pharmacological screening of plants recommended by folk medicine as anti-snake venom: I. Analgesic and anti-inflammatory activities. Mem Inst Oswaldo Cruz. 1991;86(Suppl 2):203-5.
66. Badilla B, Chaves F, Mora G, Poveda LJ. Edema induced by Bothrops asper (Squamata: Viperidae) snake venom and its inhibition by Costa Rican plant extracts. Rev Biol Trop. 2006;54(2):245-52.

67. Pereira IC, Barbosa AM, Salvador MJ, Soares AM, Ribeiro W, Cogo JC, Zamuner SR. Anti-inflammatory activity of Blutaparon portulacoides ethanolic extract against the inflammatory reaction induced by Bothrops jararacussu venom and isolated myotoxins BthTX-I and II. J Venom Anim Toxins incl Trop Dis. 2009;15(3):527-45. http://www.scielo.br/scielo. php?script=sci_arttext\&pid=\$1678-91992009000300013.

68. Maroyi A. Nutraceutical and Ethnopharmacological Properties of Vangueria infausta subsp. infausta. Molecules. 2018;23(5):pii: E1089.

69. Melima-Hage LI, Sampaio SV, Taft CA, Silva CH. Phospholipase $A_{2}$ inhibitors isolated from medicinal plants: alternative treatment against snakebites. Mini Rev Med Chem. 2013;13(9):1348-56.

70. Carvalho BM, Santos JD, Xavier BM, Almeida JR, Resende LM, Martins W, et al. Snake venom PLA $\mathrm{S}_{2}$ inhibitors isolated from Brazilian plants: synthetic and natural molecules. Biomed Res Int. 2013;2013:153045.

71. Martz W. Plants with a reputation against snakebite. Toxicon. 1992;30(10):1131-42.

72. Ushanandini S, Nagaraju S, Nayaka SC, Kumar KH, Kemparaju K, Girish KS. The anti-ophidian properties of Anacardium occidentale bark extract. Immunopharmacol Immunotoxicol. 2009;31(4):607-15.

73. Gopi K, Renu K, Jayaraman G. Inhibition of Naja naja venom enzymes by the methanolic extract of Leucas aspera and its chemical profile by GC-MS. Toxicol Rep. 2014;1:667-73.

74. Gómez-Betancur I, Benjumea D. Traditional use of the genus Renealmia and Renealmia alpinia (Rottb.) Maas (Zingiberaceae)-a review in the treatment of snakebites. Asian Pac J Trop Med. 2014;7S1:S574-82.

75. Gómez-Betancur I, Benjumea D, Patiño A, Jiménez N, Osorio E. Inhibition of the toxic effects of Bothrops asper venom by pinostrobin, a flavanone isolated from Renealmia alpinia (Rottb.) MAAS. J Ethnopharmacol. 2014;155(3):1609-15.

76. de Moura VM, Freitas de Sousa LA, Cristina Dos-Santos M, Almeida Raposo JD, Evangelista Lima A, de Oliveira RB, et al. Plants used to treat snakebites in Santarém, western Pará, Brazil: an assessment of their effectiveness in inhibiting hemorrhagic activity induced by Bothrops jararaca venom. J Ethnopharmacol. 2015;161:224-32.

77. Hung YC, Sava V, Hong MY, Huang GS. Inhibitory effects on phospholipase $\mathrm{A}_{2}$ and antivenin activity of melanin extracted from Thea sinensis Linn. Life Sci. 2004;74(16):2037-47.

78. Castro O, Gutiérrez JM, Barrios M, Castro I, Romera M, Umaña E. [Neutralization of hemorragic effects induced by the venom of Bothrops asper (Serpentes:Viperidae) by tropical plant extracts]. Rev Biol Trop. 1999;47(3):605-16. [Article in Spanish].

79. Bhattacharjee $P$, Bhattacharyya D. Characterization of the aqueous extract of the root of Aristolochia indica: evaluation of its traditional use as an antidote for snake bites. J Ethnopharmacol. 2013;145(1):220-6.

80. Vishwanath BS, Gowda TV. Interaction of aristolochic acid with Vipera russelli phospholipase $A_{2}$ : its effect on enzymatic and pathological activities. Toxicon. 1987;25(9):929-37.

81. Vishwanath BS, Appu Rao AG, Gowda TV. Interaction of phospholipase $\mathrm{A}_{2}$ from Vipera russelli venom with aristolochic acid: a circular dichroism study. Toxicon. 1987;25(9):939-46.

82. Akunyili DN, Akubue PI. Schumanniofoside, the antisnake venom principle from the stem bark of Schumanniophyton magnificum Harms. J Ethnopharmacol. 1986;18(2):167-72.

83. Houghton PJ, Osibogun IM, Bansal S. A peptide from Schumanniophyton magnificum with anti-cobra venom activity. Planta Med. 1992;58(3):263-5.

84. Gréma M, Koné PP. Effets du venin d'un serpent (Bitis arietans) et d'une plante antivenimeuse de la pharmacopée traditionnelle africaine (Annona senegalensis) au niveau de la jonction nerf sciatique-muscle gastrocnémien de crapaud (Buffo regularis). Rev CAMES. 2003;2:79-85.

85. Emmanuel A, Ebinbin A, Amlabu W. Detoxification of Echis ocellatus venom-induced toxicity by Annona senegalensis Pers. J Complement Integr Med. 2014;11(2):93-7. 
86. Guerranti R, Aguiyi JC, Errico E, Pagani R, Marinello E. Effects of Mucuna pruriens extract on activation of prothrombin by Echis carinatus venom. J Ethnopharmacol. 2001;75(2-3):175-80.

87. Tan NH, Fung SY, Sim SM, Marinello E, Guerranti R, Aguiyi JC. The protective effect of Mucuna pruriens seeds against snake venom poisoning. J Ethnopharmacol. 2009;123(2):356-8.

88. Guerranti R, Ogueli IG, Bertocci E, Muzzi C, Aguiyi JC, Cianti R, et al. Proteomic analysis of the pathophysiological process involved in the antisnake venom effect of Mucuna pruriens extract. Proteomics. 2008;8(2):402-12.

89. Shabbir A, Shahzad M, Masci P, Gobe GC. Protective activity of medicinal plants and their isolated compounds against the toxic effects from the venom of Naja (cobra) species. J Ethnopharmacol. 2014;157:222-7.

90. Molla AE, Asfaw Z, Kelbessa E, Nagappan R. Ethnobotanical study of Traditional Medicinal plants in and around Fiche District, Central Ethiopia. Curr Res J Biol Sci. 2014;6(4):154-67.

91. Bekalo TH, Woodmatas SD, Woldemariam ZA. An ethnobotanical study of medicinal plants used by local people in the lowlands of Konta Special Woreda, southern nations, nationalities and peoples regional state, Ethiopia. J Ethnobiol Ethnomed. 2009;5:26.

92. Giday M, Teklehaymanot T. Ethnobotanical study of plants used in management of livestock health problems by Afar people of Ada'ar District, Afar Regional State, Ethiopia. J Ethnobiol Ethnomed. 2013;9:8.

93. Chekole G. Ethnobotanical study of medicinal plants used against human ailments in Gubalafto District, Northern Ethiopia.J Ethnobiol Ethnomed. 2017;13(1):55.

94. Seifu T. Ethnobotanical and ethnopharmaceutical studies on medicinal plants of Chifra District, Afar Region, North Eastern Ethiopia. MSc Thesis, Addis Ababa University, School of Graduate Studies, 2004.

95. Teklehaymanot T. An ethnobotanical survey of medicinal and edible plants of Yalo Woreda in Afar regional state, Ethiopia. J Ethnobiol Ethnomed. 2017;13(1):40.

96. Getaneh S, Girma Z. An ethnobotanical study of medicinal plants in Debre Libanos Wereda, Central Ethiopia. Afr J Plant Sci. 2014;8(7):366-79.

97. Belayneh A, Bussa NF. Ethnomedicinal plants used to treat human ailments in the prehistoric place of Harla and Dengego valleys, eastern Ethiopia. J Ethnobiol Ethnomed. 2014;10:18.

98. Teklay A, Abera B, Giday M. An ethnobotanical study of medicinal plants used in Kilte Awulaelo District, Tigray Region of Ethiopia. J Ethnobiol Ethnomed. 2013;9(1):65.

99. Teklay A. Traditional medicinal plants for ethnoveterinary medicine used in Kilte Awulaelo District, Tigray Region, Northern Ethiopia. Adv Med Plant Res. 2015;3(4):137-50.

100. Belayneh A, Asfaw Z, Demissew S, Bussa NF. Medicinal plants potential and use by pastoral and agro-pastoral communities in Erer Valley of Babile Wereda, Eastern Ethiopia. J Ethnobiol Ethnomed. 2012;8:42.

101. Mengistu M, Kebede E, Serda B. Ethnobotanical knowledge of pastoral community for treating livestock diseases in Shinle Zone, Somali Regional State, Eastern Ethiopia. J Vet Sci Technol. 2017;8:474.

102. Meragiaw M. Wild useful plants with emphasis on traditional use of medicinal and edible plants by the people of Aba' ala, North-eastern Ethiopia. J Med Plant Herb Ther Res. 2016;4(1):1-16.

103. Lulekal E, Asfaw Z, Kelbessa E, Van Damme P. Ethnomedicinal study of plants used for human ailments in Ankober District, North Shewa Zone, Amhara Region, Ethiopia. J Ethnobiol Ethnomed. 2013;9(1):63.

104. Tolossa K, Debela E, Athanasiadou S, Tolera A, Ganga G, Houdijk JG. Ethno-medicinal study of plants used for treatment of human and livestock ailments by traditional healers in South Omo, Southern Ethiopia. J Ethnobiol Ethnomed. 2013;9:32.

105. Eshete MA. Ethnobotanical study of Medicinal Plants in Guji Agro-pastoralists, Blue Hora District of Borana Zone, Oromia Region, Ethiopia. MSc Thesis, Addis Ababa University School of Graduate Studies, 2011.https://www. google.fr/url?sa=t\&rct=j\&q=\&esrc=s\&source=web\&cd=2\&ved=0ahUKEwjBl8K41d_bAhUJaRQKHebNCrMQFggzMAE\&url=https\%3A\%2F\%2Fwww. ephi.gov.et\%2Fimages\%2Fpictures\%2Fdownload2010\%2FTRDMED\%2FGuji\%2520zone.pdf\&usg=AOvVaw2WyY3ZWikOw9KTXNQrPB65; Accessed June 19, 2018.
106. Eshete MA, Kelbessa E, Dalle G. Ethnobotanical study of medicinal plants in Guji Agro-pastoralists, Blue Hora District of Borana Zone, Oromia Region, Ethiopia. J Med Plants Stud. 2016;4(2):170-84.

107. Chekole G, Asfaw Z, Kelbessa E. Ethnobotanical study of medicinal plants in the environs of Tara-gedam and Amba remnant forests of Libo Kemkem District, northwest Ethiopia. J Ethnobiol Ethnomed. 2015;11:4.

108. Sori T, Bekana M, Adugna G, Kelbessa E. Medicinal plants in the ethnoveterinary practices of Borana pastoralists, Southern Ethiopia. Int J Appl Res Vet Med. 2004;2(3):220-5.

109. Kidane B, van Andel T, van der Maesen LJ, Asfaw Z. Use and management of traditional medicinal plants by Maale and Ari ethnic communities in southern Ethiopia. J Ethnobiol Ethnomed. 2014;10:46.

110. Teklehaymanot T. Ethnobotanical study of knowledge and medicinal plants use by the people in Dek Island in Ethiopia. J Ethnopharmacol. 2009;124(1):69-78.

111. Abebe E. Ethnobotanical study on medicinal plants used by local communities in Debark Wereda, North Gondar Zone, Amhara Regional State, Ethiopia. MSc. Thesis Addis Ababa University, School of Graduate Studies, 2011. https://www.google.fr/url?sa=t\&rct=j\&$q=\& e s r c=s \&$ source $=$ web\& $c d=3 \& v e d=0 a h U K E w j E h 9 G 8 q 9 \_b A h U$ DUBQKHfQ4Ag8QFgg-MAI\&url=http\%3A\%2F\%2Fciteseerx.ist.psu. edu\%2Fviewdoc\%2Fdownload\%3Fdoi\%3D10.1.1.465.4562\%26rep\%3Drep1\%26type\%3Dpdf\&usg=AOvVaw2ofbj7I2CqGYdjXQbk3wBd; Accessed June 19, 2018.

112. Meragiaw M, Asfaw Z, Argaw M. The status of ethnobotanical knowledge of medicinal plants and the impacts of resettlement in Delanta, Northwestern Wello, Northern Ethiopia. Evid Based Complement Alternat Med. 2016;2016:5060247.

113. Teklehaymanot T, Giday M, Medhin G, Mekonnen Y. Knowledge and use of medicinal plants by people around Debre Libanos monastery in Ethiopia. J Ethnopharmacol. 2007;111(2):271-83.

114. Lulekal E, Asfaw Z, Kelbessa E, Van Damme P. Ethnoveterinary plants of Ankober District, North Shewa Zone, Amhara Region, Ethiopia. J Ethnobiol Ethnomed. 2014;10:21.

115. Feyera T, Mekonnen E, Wakayo BU, Assefa S. Botanical ethnoveterinary therapies used by agro-pastoralists of Fafan zone, Eastern Ethiopia. BMC Vet Res. 2017;13(1):232.

116. Kebede A, Ayalew S, Mesfin A, Mulualem G. An ethnoveterinary study of medicinal plants used for the management of livestock ailments in selected kebeles of Dire Dawa Administration, Eastern Ethiopia. J Plant Sci. 2017;5(1):34-42.

117. Kaushik A, Ambesajir A, Kaushik JJ, Girmay B. Snake venom neutralization effects of African Medicinal Plants \& Their Impact on Snakebites: a review. Asian J Biomed Pharm Sci. 2013;3(24):1-6.

118. Teklehaymanot T, Giday M. Ethnobotanical study of medicinal plants used by people in Zegie Peninsula, Northwestern Ethiopia. J Ethnobiol Ethnomed. 2007:3:12.

119. Eshetu GR, Dejene TA, Telila LB, Bekele DF. Ethnoveterinary medicinal plants: Preparation and application methods by traditional healers in selected districts of southern Ethiopia. Vet World. 2015;8(5):674-84.

120. Amenu E. Use and Management of Medicinal Plants by Indigenous People of Ejaji Area (Chelya Woreda) West Shoa, Ethiopia: an Ethnobotanical Approach. MSc Thesis, Addis Ababa University School of Graduate Studies. 2007.https://www.google.fr/url?sa=t\&rct=j\&q=\&esrc=s\&source=web\&c$\mathrm{d}=2 \&$ ved=0ahUKEwi8m9uRguDbAhVB7BQKHZOgAUMQFggxMAE\&urI=http\%3A\%2F\%2Fwww.ethnopharmacologia.org\%2Fprelude2018\%2Fpdf\%2Fbiblio-ha-53-amenu.pdf\&usg=AOvVaw20bMb5Ztdu-2SxOz30Zrpd; Accessed June 19, 2018.

121. Giday M, Asfaw Z, Woldu Z. Medicinal plants of the Meinit ethnic group of Ethiopia: an ethnobotanical study. J Ethnopharmacol. 2009;124(3):51321.

122. Bekele G, Reddy PR. Ethnobotanical study of medicinal plants used to treat human ailments by Guji Oromo Tribes in Abaya District. Univ J Plant Sci. 2015;3(1):1-8.

123. Mengesha GG. Ethnobotanical survey of medicinal plants used in treating human and livestock health problems in Mandura Woreda of Benishangul Gumuz, Ethiopia. Adv Med Plant Res. 2016;4(1):11-26. 
124. Giday M, Teklehaymanot T, Animut A, Mekonnen Y. Medicinal plants of the Shinasha, Agew-awi and Amhara peoples in northwest Ethiopia. J Ethnopharmacol. 2007;110(3):516-25.

125. Birhanu A, Haji F. Ethnobotanical study of medicinal plants used for the treatment of human and livestock ailments in Dawe Kachen District of Bale Zone, Southeast Ethiopia. Int J Emerg Trends Sci Technol. 2017;4(4):5043-55.

126. Kitaba NT. Ecology and Plant use diversity in Sof Umer area of Bale, Southeastern Ethiopia. MSc Thesis, Addis Ababa University School of Graduate Studies. 2006.

127. Girmay T, Teshome Z. Assessment of Traditional Medicinal Plants used to treat human and livestock ailments and their threatening factors in Gulomekeda District, Northern Ethiopia. Int J Emerg Trends Sci Technol. 2017;4(4):5061-70.

128. Gebretsadkan T. Ethnobotanical study of medicinal plants used by people of Gog District, Agnuak Zone, Gambella Regional State of Ethiopia. MSc Thesis, Haramaya University, 2017.

129. Asmamaw D, Achamyeleh $\mathrm{H}$. Assessment of medicinal plants and their conservation status in case of Daligaw Kebela, Gozamen Werda, East Gojjam Zone. J Biodivers Biopros Dev. 2018;5(1):170.

130. Zelalem G, Subramanian C, Getinet M. Studies on traditional medicinal plants in Ambagiorgis area of Wogera District, Amhara Regional State, Ethiopia. Int J Pure App Biosci. 2016;4(2):38-45.

131. Legesse GA. Plant diversity and ethnobotany of medicinal and wild edible plants in Amaro District of Southern Nations, Nationalities and People Region and Gelana District of Oromia Region, Southern Ethiopia. PhD Dissertation, Addis Ababa University, Ethiopia. 2017.

132. Demie G, Negash M, Awas T. Ethnobotanical study of medicinal plants used by indigenous people in and around Dirre Sheikh Hussein heritage site of South-eastern Ethiopia. J Ethnopharmacol. 2018;220:87-93.

133. Beche D, Gebeyehu G, Feyisa K. Indigenous utilization and management of useful plants in and around Awash National Park, Ethiopia. J Plant Biol Soil Health. 2016;3(1):12.

134. Alito MK. Use and management of medicinal plants by indigenous people of Jima Rare District in Oromia Region, Ethiopia. MSc Thesis, Haramaya University, School of Graduate Study. 2014.

135. Zerabruk S, Yirga G. Traditional knowledge of medicinal plants in Gindeberet district, Western Ethiopia. South Afr J Bot. 2012;78(1):165-9.

136. Wondimu T, Asfaw Z, Kelbessa E. Ethnobotanical study of medicinal plants around 'Dheeraa' town, Arsi Zone, Ethiopia. J Ethnopharmacol. 2007;112(1):152-61.

137. Alebie G, Mehamed A. An ethno-botanical study of medicinal plants in Jigjiga town, capital city of Somali regional state of Ethiopia. Int J Herbal Med. 2016;4(6):168-75.

138. Temam T, Dillo A. Ethnobotanical study of medicinal plants of MirabBadwacho district, Ethiopia. J BioSci Biotechnol. 2016;5(2):151-8.

139. Birhanu T, Abera D, Ejeta E. Ethnobotanical study of medicinal plants in selected Horro Gudurru Woredas, Western Ethiopia. J Biol Agr Healthcare. 2015;5(1):83-93.

140. Kefalew A, Asfaw Z, Kelbessa E. Ethnobotany of medicinal plants in Ada'a District, East Shewa Zone of Oromia Regional State, Ethiopia. J Ethnobiol Ethnomed. 2015;11:25.

141. Limenih Y, Umer S, Wolde-Mariam M. Ethnobotanical study on traditional medicinal plants in Dega Damot Woreda, Amhara Region, North Ethiopia. Int J Res Pharm Chem. 2015;5(2):258-73.

142. Yirga G, Teferi M, Brhane G, Amare S. Plants used in ethnoveterinary practices in Medebay- Zana District, Northern Ethiopia. J Med Plant Res. 2012;6(3):433-8.

143. Beyene ST. An ethnobotanical study of medicinal plants in Wondo Genet Natural Forest AND Adjacent Kebeles, Sidama Zone, SNNP Re- gion, Ethiopia. MSc Thesis, Addis Ababa University, School of Graduate Studies. 2011.https://www.google.fr/url?sa=t\&rct=j\&q=\&esrc=s\&source=web\&cd=1\&ved=0ahUKEwjvhKCdt9_bAhVOlxQKHTy4BkoQFggnMAA\&url=https\%3A\%2F\%2Fwww.ephi.gov.et\%2Fimages\%2Fpictures\%2Fdownload2010\%2FTRDMED\%2FWondo\%2520Genet\%2520Natural. pdf\&usg=AOvVaw0RY27UvPNjsEVeoic8pvPU; accessed June 19, 2018.

144. Paulos B, Fenta TG, Bisrat D, Asres K. Health seeking behavior and use of medicinal plants among the Hamer ethnic group, South Omo zone, southwestern Ethiopia. J Ethnobiol Ethnomed. 2016;12(1):44.

145. Yirga G. Assessment of traditional medicinal plants in Endrta District, South-eastern Tigray, Northern Ethiopia. Afr J Plant Sci. 2010;4(7):25560.

146. Abera B. Medicinal plants used in traditional medicine by Oromo people, Ghimbi District, Southwest Ethiopia. J Ethnobiol Ethnomed. 2014;10:40.

147. Amsalu N, Bezie Y, Fentahun M, Alemayehu A, Amsalu G. Use and conservation of medicinal plants by indigenous people of Gozamin Wereda, East Gojjam Zone of Amhara Region, Ethiopia: An Ethnobotanical Approach. Evid Based Comp Altern Med. 2018;2018:2973513.

148. Birhan YS, Kitaw SL, Alemayehu YA, Mengesha NM. Ethnoveterinary medicinal plants and practices in Enarj Enawga District, East Gojjam Zone, Amhara Region, Ethiopia. Int J Anim Sci. 2018;2(1):1014.

149. Giday M, Asfaw Z, Woldu Z, Teklehaymanot T. Medicinal plant knowledge of the Bench ethnic group of Ethiopia: an ethnobotanical investigation. J Ethnobiol Ethnomed. 2009;5:34.

150. Giday K, Lenaerts L, Gebrehiwot K, Yirga G, Verbist B, Muys B. Ethnobotanical study of medicinal plants from degraded dry afromontane forest in northern Ethiopia: Species, uses and conservation challenges. J Herb Med. 2016;6(2):96-104.

151. Kewessa G, Abebe T, Demessie A. Indigenous knowledge on the use and management of medicinal trees and shrubs in Dale District, Sidama Zone, Southern Ethiopia. Ethnobot Res Appl. 2015;14:171-82.

152. Lulekal E, Kelbessa E, Bekele T, Yineger H. An ethnobotanical study of medicinal plants in Mana Angetu District, southeastern Ethiopia. J Ethnobiol Ethnomed. 2008;4:10.

153. Tuasha N, Petros B, Asfaw Z. Medicinal plants used by traditional healers to treat malignancies and other human ailments in Dalle District, Sidama Zone, Ethiopia. J Ethnobiol Ethnomed. 2018;14(1):15.

154. Yineger $\mathrm{H}$, Kelbessa E, Bekele T, Lulekal E. Ethnoveterinary medicinal plants at Bale Mountains National Park, Ethiopia. J Ethnopharmacol. 2007;112(1):55-70.

155. Allabi AC, Busia K, Ekanmian V, Bakiono F. The use of medicinal plants in self-care in the Agonlin region of Benin. J Ethnopharmacol. 2011;133(1):23443.

156. Chahad AM, Michalet S, Bechir AB, Tidjani A, Nkongmeneck BA, DijouxFranca MG. Medicinal plants from the Ouaddaï Province (Chad): An ethnobotanical survey of plants used in traditional medicine. J Altern Complement Med. 2015;21(9):569-77.

157. Yemane B, Medhanie G, Surender Reddy K. Survey of some common medicinal plants used in Eritrean folk medicine. Am J Ethnomed. 2017;4(2):14.

158. Yemane B, Andebrhan M, Surender Reddy K. Traditional medicinal plants used by Tigrigna Ethnic Group in Central Region Of Eritrea. IOSR J Pharm Biol Sci. 2017;12(3):40-6.

159. Gakuubi MM, Wanzala W. A survey of plants and plant products traditionally used in livestock health management in Buuri district, Meru County, Kenya. J Ethnobiol Ethnomed. 2012;8:39.

160. Tshikalange TE, Mophuting BC, Mahore J, Winterboer S, Lall N. An ethnobotanical study of medicinal plants used in villages under Jongilanga tribal council, Mpumalanga, South Africa. Afr J Tradit Complement Altern Med. 2016;13(6):83-9. 